FOR THE RECORD... On Métis Identity and Citizenship Within the Métis Nation

\author{
Tony Belcourt \\ Founding President, Native Council of Canada \\ Founding President, Métis Nation of Ontario
}

aboriginal policy studies Vol. 2, no. 2, 2013, pp. 128-141

This article can be found at:

http://ejournals.library.ualberta.ca/index.php/aps/article/view/19010

ISSN: $1923-3299$

Article DOI: http://dx.doi.org/10.5663/aps.v2i2.19010

aboriginal policy studies is an online, peer-reviewed and multidisciplinary journal that publishes original, scholarly, and policy-relevant research on issues relevant to Métis, non-status Indians and urban Aboriginal people in Canada. For more information, please contact us at apsjournal@ualberta.ca or visit our website at www.ualberta.ca/nativestudies/aps/.

UNIVERSITY OF ALBERTA

FACULTY OF NATIVE STUDIES
Aboriginal Affairs and

Northern Development Canada

Affaires autochtones et Développement du Nord Canada 


\title{
FOR THE RECORD... On Métis Identity and Citizenship Within the Métis Nation
}

\author{
Tony Belcourt \\ Founding President, Native Council of Canada \\ Founding President, Métis Nation of Ontario
}

Métis National Council (MNC) President Clem Chartier, in his February 2013 newsletter, ${ }^{1}$ mentioned the Native Council of Canada, the Métis Nation of Ontario (MNO), and me a number of times while citing unresolved "issues," the existence of which he blamed on the MNC's "failure to reach consensus on the Homeland boundaries and a national acceptance process for Métis Nation Citizenship." I am compelled to write to set the record straight based on history and fact.

\section{President Chartier writes:}

We stand on the edge of a new frontier for Métis Nation self-government. The Daniels case, the upcoming decision of the Supreme Court of Canada in MMFv Canada and Manitoba, and the accords under the Métis Nation Protocol are all building blocks underlying a potential self-government agreement between the Métis Nation and Canada. But there are stumbling blocks too that must be overcome if we are to reach consensus on a constitution that we need in order to exercise self-government. The foremost of these is the failure to date to achieve consensus on Homeland boundaries and a national acceptance process for Métis Nation citizenship. Without settling these issues, we cannot capitalize on the opportunities for self-government currently unfolding before us.

These issues take us back to the organization of the Métis at the national level in 1971 when the three prairie Métis associations founded the Native Council of Canada (NCC). By 1983, those same three prairie Métis organizations found it necessary to leave the organization they had founded because, with the expansion of the NCC to include non-status and status Indians, the Métis had become a minority in its governance structure and could no longer effectively advocate for Métis Nation rights, particularly with respect to the pending First Ministers Conferences on Aboriginal Rights. With the formation of the Métis National Council as the sole legitimate representative of the Métis Nation on March 8, 1983 we were able to secure our rightful place at the constitutional negotiation table and advocate for a Métis Nation land-base and self-government.

1 Métis National Council President's Newsletter-February 2013 Special Edition "Message from Clément Chartier-DANIELS CASE: A WAKE-UP CALL," http://www.metisnation.ca/wp-content/uploads/2013/02/ PDF-Draft-Newsletter-Feb-2013.pdf.

aboriginal policy studies, Vol. 2, no. 2, 2013 
It's regrettable that the case of $R v$. Powley, which recognized the existing Métis right to hunt and fish for food, was not listed as being one the of "building blocks underlying a potential self-government agreement between the Métis Nation and Canada."

The decision to create a national organization to represent our interests in Ottawa was made on 16 November 1970, the eighty-fifth anniversary of the hanging of Louis Riel. This was a momentous gathering of the leaders of the Métis and Non-Status Indian associations of the Prairies and British Columbia and I consider it a great privilege to have taken part in such a seminal event in our history.

The leaders met in a small hotel room in Victoria, British Columbia: Angus Spence, President of the Manitoba Métis Federation (MMF); Jim Sinclair, Vice-President of the Association of Métis and Non-Status Indians of Saskatchewan (AMNSIS); Stan Daniels, President of the Métis Association of Alberta (MAA); myself as Vice-President of the Métis Association of Alberta; and Butch Smitheram, President of the BC Association of NonStatus Indians (BCANSI). We chose to meet in Victoria so we could also attend the First Annual General Assembly of BCANSI, which was also taking place at the time.

We met at my urging because I felt we needed to have a presence in Ottawa if we were to gain federal recognition of our rights and address the call by our people to get a land base for Métis. We agreed to form an interim steering committee to consider our options. Jim Sinclair was appointed Chair and I was appointed Secretary.

Jim Sinclair and I traveled to Hamilton, Ontario early in 1971 at the invitation of the Hon. John Munro, then Minister of National Health and Welfare. We hitchhiked a ride from there to Ottawa on his government plane.

That's what we did in those days when we didn't have any money for travel. Besides, we took advantage of any opportunity to get some time with ministers and others in positions of power. We talked the Minister's head off about the deplorable health conditions of our people and the need for us to get organized to address them. Anyone who knew Jim Sinclair knew how persuasive he could be. We needed money and we asked for it. While we were in the air, halfway to Ottawa, the Minister turned to one of his aides and said: "Find $\$ 10,000$ somewhere to get these guys off my back."

The same representatives of Métis and Non-Status Indians present in Victoria in November 1970 met in Ottawa in April 1971. We also invited Paddy McGuire, Sr., then President of the Lake Nipigon Métis Association (of Ontario), to join us. His son, Mike McGuire, was also there.

It was at this meeting that we decided to form a national organization and to call it the Native Council of Canada (Métis \& Non-Status Indians). ${ }^{2}$ We made a deliberate and collective decision to build a national organization that would include both Métis and NonStatus Indians for two reasons: first, because it reflected the reality of the membership of all of our organizations at the time; and, second, because we shared the same goals and were in basically the same position-landless and without federal recognition.

We also decided to assist Métis and Non-status Indians in the NWT, Yukon, and the provinces to form organizations and join the NCC in order to strengthen our collective

2 The bracketed words "Métis and Non-Status Indians" was part of the formal name of the Native Council of Canada. 
voice and lobbying power. Our first need, however, was to get the funding that would enable us to operate a national office and help the other organizations get off the ground.

I was elected President of the Native Council of Canada at our founding meeting in April. On the strength of a $\$ 10,000$ loan to the NCC from the Métis Association of Alberta, I moved my family to Ottawa. Thankfully for us, we were very fortunate to have "friends on the inside"; federal public servants who were sympathetic to our cause and who were eager to assist.

One morning, I found a "draft Memorandum to Cabinet" that had been slipped under my door. The federal government was about to launch a funding program limited to "Status Indians 3 ." I issued a statement to the media, releasing the information and calling on the government to open up the policy to include the Métis and Non-Status Indians. The political agenda at the time, championed by Prime Minister Pierre Trudeau, was about "participatory democracy" and a "just society." We said, who needs that more than us?

We got a meeting with the Hon. Bob Stanbury, Minister of State for Citizenship, in June. We agreed to meet at the Beacon Arms Hotel on Albert Street in Ottawa. I called all the provincial presidents in for the meeting and also tipped off the press that the meeting was taking place. When the Minister arrived, the hallway was jam-packed with television cameras and reporters.

The Minister told us that it would be difficult to get it changed. We kept the Minister there for a long time, all of the leaders telling him about conditions in our communities and the issues we had to address-poverty, poor health, deplorable housing. We had seated him at the far end of the room-the furthest point away from the door. He was not only feeling our pressure, he knew the media were waiting for him too. Finally, he gave us a commitment to go to Cabinet to include the Métis in federal funding polices. We also asked him to make sure to include the Inuit too because they weren't organized and shouldn't be left out just because they didn't have anyone in Ottawa to speak for them.

A month later, in August, while I was attending the Annual General Assembly of the Métis Association of Alberta in Lac La Biche, I got a message to call Minister Stanbury. He said he was pleased to report that the federal government had decided to include the Métis and Non-Status Indians in its "core-funding" policy ${ }^{4}$ and that I was welcome to make that announcement at the Assembly. It was the Native Council of Canada's first achievement and it was an important one. Without any funding, we were in no position to be able to organize, do research, prepare briefs, and lobby to bring about change in the communities for our people.

We quickly organized the Ontario Métis and Non-Status Indian Association (OMNSIA), the Laurentian Alliance of Métis and Non-Status Indians of Quebec, the New Brunswick Métis \& Non-Status Indian Association, the Non-Status Indian and Métis Association of Nova Scotia, the P.E.I Association of Métis \& Non-Status Indians, Indian and Métis Association of Newfoundland and Labrador, Yukon Association of Non-Status Indians, and

3 Canada, Cabinet Conclusion, "Native culture/education centres," 17 July 1971, RG-2, Series A-5a, Volume 6381, Library and Archives Canada.

4 Canada, Cabinet Conclusion, "Financial assistance and grants policy to native associations," 29 July 1971, RG-2, Series A-5a, Volume 6381, Library and Archives Canada. 
the Métis Association of the NWT. Together with the MMF, AMNSIS, MAA, and BCANSI, the NCC now represented Métis and Non-Status Indians from coast to coast.

We achieved much by joining forces and working together, not the least of which was a federal policy to provide millions of dollars for the emergency repair of the dilapidated shacks and run-down homes so many of our people were living in at the time: money to fix shacks with leaking roofs and nothing to block the bitter winter winds from howling through the holes in the walls or broken windows; to relieve overcrowded shacks, where the only warmth and place to cook came from an old oil barrel cut in half to serve as the heater and the stove-situations where barrels would overheat, explode, and endanger-in fact take the lives of-countless Métis families.

Thanks to a great "friend on the inside" at the Canada Mortgage and Housing Corporation, Walter Rudnicki, ${ }^{5}$ we were successful in obtaining a "Rural and Native Housing Policy" with the commitment to build 50,000 new homes within five years. This was soon followed by an Urban Native Housing Policy that saw tens of thousands of homes being bought, renovated, and made available to our people through affordable, subsidized housing programs established by various non-profit housing corporations set up by our organizations within each province. If you were not there at the time to see the needs, where housing was either not available or simply not available to our people because of discrimination, then it is difficult to illustrate how much it meant to Métis and Non-Status Indian families to finally have a warm, healthy, and secure place to live and bring up their children.

Our accomplishments, created by joining forces through the NCC, were featured in the report of the Royal Commission on Aboriginal Peoples (RCAP) in 1996:

The NCC's greatest achievement, in collaboration with other Aboriginal organizations, was to persuade federal and provincial politicians to agree to the entrenchment of "the existing Aboriginal and treaty rights of the Aboriginal peoples of Canada" in section 35 of the Constitution Act, 1982, and to insist that Aboriginal peoples be defined in section 35(2) to include Métis people.

This monumental turning point in Métis history would not have been possible without the hard work of everyone: leaders and staff of the NCC and all of the organizations. We especially owe a debt of gratitude to Harry Daniels, NCC President in 1981, when he stood his ground to ensure that the Constitution Act, 1982 included a clause defining who the Aboriginal peoples were and that "Métis" be included.

President Chartier correctly points out that the "three prairie Métis Associations found it necessary to leave the organization (NCC) ..." in 1983. By this time, the NCC Board of Directors, headed by Smokey Bruyere, consisted predominantly of Non-Status Indians.

5 Walter Rudnicki was Executive Director at CMHC in the early seventies. His policy branch provided funding to NCC member organizations to document the appalling housing conditions of Métis and NonStatus Indians. These reports formed the basis for development of the Rural and Native Housing Policy. In 1973, he was fired from his job because he allegedly showed a "confidential Cabinet document" to members of the NCC. He sued the government for wrongful dismissal and won his case, but he was never able to get re-instated as a senior federal public servant. For further info, see Walter Rudnicki's full collection of all his archived documents in University of Manitoba Libraries at http://ow.ly/hznh1. 
The Board refused to allow one of its Métis representatives to take one of the two seats set aside for the NCC at the pending First Ministers Conferences on Aboriginal Rights.

Personally, having been the founding President of the NCC, I was deeply disappointed that the Board did not see that, without a Métis person occupying one of its seats at a Constitutional Conference called to elaborate the meaning of the Aboriginal and Treaty Rights of the Aboriginal peoples, including the rights of the Métis, it no longer had any legitimacy in claiming to represent the Métis of the Prairies.

President Chartier further states:

The Métis Nation of Ontario became part of the MNC in 1994/95 with Tony Belcourt as its President. In the absence of a formalized national identification and registry system, the $\mathrm{MNO}$, acting in isolation, adopted a policy and application form through which it identified as a citizen of the Métis Nation any individual who could provide proof that they had at least one grandparent who was either Métis, Indian or Inuit. This was basically the old NCC definition of Métis and in contravention of the criteria used by the MNC since its creation in 1983 based on Métis Nation descent only.

The facts are these:

1. The Métis Nation of Ontario became part of the MNC at its annual meeting in 1994.

2. The Métis Nation of Ontario, at its Founding Delegates Assembly, 5-7 May 1994, adopted the following motion:

Motion \#10: Move the following definition:

Anyone of Aboriginal ancestry who self-identifies as Métis, is distinct from Indian or Inuit and who is accepted by the Métis Nation of Ontario, is Métis. A person is entitled to be registered as a citizen of the Métis Nation of Ontario who:

- is alive,

- self-identifies as Métis,

- is distinct from Indian or Inuit,

- has genealogical ties to Aboriginal ancestry,

- is accepted by the Métis Nation of Ontario,

- is not enrolled on any other Aboriginal registry. 
Gerald Thom, President of the Métis Association of Alberta, and Gerald Morin, President of the Métis Society of Saskatchewan, were present at the MNO's Founding Delegates Assembly. They were also present later that year, along with Billy Joe Delaronde, President of the Manitoba Métis Federation, when the MNO was admitted into membership at the MNC Special Assembly in November 1994. The MNO definition at the time was not a bar to its admission as a member of the MNC, nor was it ever brought up. Instead, I always remember what a joyous occasion this was for all of us. There were cheers and applause when the resolution was passed.

President Chartier states that, "criteria used by the MNC since its creation in 1983 (was) based on Métis Nation descent only."

I would like to point out that, despite this being the criteria, it did not preclude NonStatus Indians from being members of the Prairie Métis organizations. This is most obvious by the fact that Jim Sinclair, a Non-Status Indian from Punnichy, Saskatchewan, was President of the Association of Métis and Non-Status Indians of Saskatchewan when the Métis National Council was created in 1983. He was one of the most prominent Aboriginal representatives during the three First Ministers' Conferences on Aboriginal Rights in the Constitution during the mid-1980s.

The First Ministers' Conference in 1987 was the final one held as required by the Constitution Act, 1982. Jim Sinclair was seated as the spokesperson for the Métis National Council. As it was about to close in abject failure, Jim delivered the most iconic speech ever given at that conference as he denounced, in particular, the premiers of BC and Saskatchewan for their refusal to reach an agreement on the Métis right of self-government and to a land base for Métis. Everyone cheered. Nobody cared that he was sitting in a seat set aside for the Métis. Everyone was justifiably proud to have such a dynamic leader speaking on our behalf.

President Chartier writes:

In the 2003 Powley case, the Supreme Court of Canada established a test for identifying Métis harvesting rights holders under section 35 of the Constitution Act that was very similar to our National Definition. It required self-identification, ancestral connection to a historic Métis community, and acceptance by a modern Métis community that evolved out of a historic Métis community. ...

As a result of the Powley decision, the federal government began providing financial support for the Governing Members of the MNC to proceed with their registering of Métis Nation citizens residing within their respective provincial jurisdictions. Each of the MNC Governing Members amended its Constitution or Bylaws to incorporate the 2002 National Definition and registration should have been limited to members who met its requirements. In the absence of a national acceptance process and a national registry, however, it was not possible to enforce the compliance of all Governing Members with the National Definition.

All of the Governing Members except for the MNO embarked on a re-registration process of all existing members based on the National Definition in order to register only those persons who can prove Métis Nation ancestry as provided therein. 
In order to understand why the MNO did not embark on a "re-registration process" in 2003 , it is necessary to provide a bit of the history of the decade of experience and development of the Métis in Ontario that led to that decision.

In 1993, Métis in Ontario were members of the Ontario Métis \& Aboriginal Association $(\mathrm{OMAA})^{6}$; Métis leaders and elders, people such as George McGuire of Thunder Bay, Edith McLeod of MacDiarmid, Gilles Lefebvre of Timmins, Marion Larkman of Bewdley, Steve Powley of Sault Ste. Marie, John Burnham of River Valley, Helen Bradley of Midland, Henry Lepage of Penetanguishene, and Earl Scofield of Windsor. Nearly five hundred people were self-identified on OMAA's membership list as being Métis.

By then, because of changes to the Indian Act (Bill C-31), many former "Non-Status" Indians had regained their Indian Status.

Ironically, similar to the situation that the Prairie Métis faced a decade earlier within the NCC when their three organizations withdrew to form the Métis National Council, Métis people in Ontario who attended annual meetings and board meetings found themselves competing for time to address their issues-Métis-specific issues.

After a hard-fought and closely won vote at an OMAA General Assembly in 1991, we formed a "Métis Commission" to focus on how we could move towards our goals of implementing Métis governance and achieving full recognition of our rights. It was because of the Métis Commission that Métis OMAA representatives found themselves working in collaboration with representatives of the Métis National Council, its governing members, and the Métis Association of the NWT during the Charlottetown round of talks in 1992 that led to development of the Métis Nation Accord. ${ }^{7}$

The Accord was an agreement between the Governments of Canada, the NWT, the Provinces of Ontario, Manitoba, Saskatchewan, Alberta and British Columbia, and the representatives of the Métis National Council, the NWT Métis Association, and the OMAA. As stated in the report of the Royal Commission on Aboriginal Peoples (vol 4: 230) they "agreed to enter into a legally binding, justiciable and enforceable accord on Métis issues ... The Accord commits governments to negotiate: self-government agreements; lands and resources; the transfer of the portion of Aboriginal programs and services available to Métis; and cost sharing agreements related to Métis institutions, programs and services."

During this time, it became clear to those of us on that Commission that we could not move our agenda forward by remaining in an umbrella lobby group; it was time for us to withdraw from OMAA and form a stand-alone organization that would represent only the interests of the Métis. This was a very stressful time for us. Separation from good friends we had worked with for decades was painful. People were deeply hurt and it caused great divisions among us, many lasting to this day.

Nevertheless, we knew what we had to do, so, in a conference call of the members of the "Métis Commission" on the evening of 2 October 1993, we decided to form the Métis Nation of Ontario and to invite all those other members of OMAA who self-identified as Métis to join us.

6 The Ontario Métis and Non-Status Indian Association changed its name to OMAA in the late 1980s.

7 The Métis Nation Accord was an Appendix to the Charlottetown Accord. Both accords died following their rejection by voters in a 1992 referendum. 
We decided to form a "Provisional Council of the Métis Nation of Ontario" and name its first members, which included the members of the Métis Commission and others to ensure complete regional representation. They were:

- Alma Adams, MacDiarmid

- Tony Belcourt, Ottawa

- Olaf Bjorna, Batchawana

- Don Cadeau, Port McNicol

- Gilbert Gervais, Timmins

- Marion Larkman, Bewdley

- Agnes Lidstone, Sault Ste. Marie

- George McGuire, Thunder Bay

- Edith McLeod, MacDiarmid

- Naomi Oig, Dryden

- Brenda Prouty, Dryden

- Ron Swain, Sault Ste. Marie

- Sharon Talbot, Blind River

- Jean Teillet, Ottawa

As mentioned earlier, we held our Founding Delegates Assembly in Toronto the following May of 1994. We were determined to follow a "rights-based" agenda, and one of our first actions was to adopt a resolution to create a legal defence fund. To show vigor and commitment to fighting for recognition of our rights, we raised almost $\$ 3,000$ from the ninety-four Métis community representatives in attendance.

Rather than forming an "non-profit association" of "members," we were determined that the MNO was going to be established with the full intention of putting in place the foundations that would serve our goal of implementing our right of self-determination and gaining full recognition of our rights.

One fundamental step was that we establish a Registry, as was specifically contemplated in Motion \#10 above, defining who may be "registered as a citizen of the Métis Nation of Ontario."

The Métis Nation of Ontario's commitment to form a Registry for its citizens is further embedded in the MNO's Statement of Prime Purpose, which states in part,

We, the Métis who live within the Métis Homelands of Ontario, desiring to bind our people together to collectively promote our common cultural, social, political, and economic wellbeing, have founded the Métis Nation of Ontario, to be our representative body with the following aims and objectives: 
1. to research, publish and promote the genealogical documentation of the Métis, and to establish and maintain a registry of the Métis citizens of Ontario ... ${ }^{8}$

The MNO established an Interim Registry Policy, based on the principles in international law of self-identity and community acceptance. This formal process began in the mid1990s in good faith. That process included the appointment of an MNO Registrar who operated at arms-length from the elected leadership, applying the criteria listed within the policy that required that applicants provide sufficient documentation to support their application. Our first registrars were all experienced Métis genealogists: Patsy McArthur, Aline Sabourin, and Karole Dumont Beckett.

The creation of the MNO Registry was also critical in support of the action being taken by MNO citizens to implement their right to hunt and fish for food. In 2001, following a victory at the Ontario Court of Appeal in Powley, the MNO issued the Métis Nation Ontario 2001 Harvesting Policy. It set out numerous provisions, including the appointment of Captains of the Hunt and the terms for issuance of MNO Harvesters' Certificates, including this clause:

4.5 For purposes of participation in the Métis harvest, a Captain of the Hunt may issue an MNO Harvester's Certificate which shall be considered proof that the holder has been verified by the MNO Registrar as having provided sufficient documentation to support a claim to an Aboriginal or treaty right to harvest. (emphasis added)

When the federal government finally began providing financial support for registry purposes after the Supreme Court decision in $R$ v. Powley in 2003, unlike other governing members of the MNC who had to establish new policies and processes and convert their "membership" enrollments accordingly, the MNO already had a well-established registry process.

With the onus on the MNO Registrar and her limited staff resources to now provide verification for the hundreds of MNO citizens who applied for Harvesters' Certificates, the Registrar also had the obligation to continue to process the backlog of thousands of applications for MNO citizenship. The pressure on the Registry staff to verify those applying for Harvesters' Certificates and process the backlog of applications was tremendous. The priority of the MNO at the time was not to "re-register" but to accelerate the registration process.

\section{President Chartier writes:}

Under President Belcourt's leadership, the MNO "grandfathered-in" their existing members, which was not endorsed by the other leaders of the Council. The MNO registration policy only applied the National Definition to new applicants post-2002.

It is important to remember, I believe, that having put out the call to invite Métis people to enroll in the newly founded MNO, we were soon inundated with applications. Without any funding, we operated from the attic of my home, and at one time there were up to fifteen volunteers crammed in up there, working away in summer's sweltering heat because

8 The MNO Statement of Prime Purpose declares who we are as a people, articulates our values, and proclaims a long list of aspirations (16), of which this is the first. 
they believed in our cause and wanted to help. Current MNO Senator Reta Gordon and her sister Lois McCallum, whose Métis ancestry comes from the historic Métis community at Moose Factory ${ }^{9}$ on the coast of James Bay, were among them.

I'll never forget receiving our first application in the mail. It was from a Métis pensioner from Timmins, Ontario, Agathe Moran. The applications came in from everywhere in Ontario, including from Senator Earl Scofield in Windsor where he, like many Métis people, had gone to work in the auto industry. Some of them, like Senator Kaye Lynch of Kenora and Senator Roland St. Germain of Owen Sound, were from the Prairies; others came from historic Métis communities in Ontario, like Ray Tucker of Ft. Francis, Jack Bouchard of Sault Ste. Marie, and Dave Jacobs from Burleigh Falls.

There was nothing at stake for any of us other than our pride. The MNO didn't have any programs or services. There were no recognized hunting and fishing rights. We did not have the Daniels ${ }^{10}$ decision in hand that ruled that the federal government has jurisdictional authority to legislate and develop policies and programs for Métis people. Quite the opposite-Métis people were regularly being charged for hunting or fishing to feed their families and put away meat for the winter.

Grandfathering-in the existing MNO citizens was the right thing to do. We have long understood this term, "grandfathering-in," because this was similar to our own custom of having ceremony for adoption or "making relatives" to bring new people into our families. We also had ceremonies to create alliances or make treaties.

Grandfathering-in is an ancient principle of the common law that the customs and practices of people who have vested rights and expectations should not be easily disturbed. In fact, because of this principle, Status Indians are today members of the Métis Settlements in Alberta because they were grandfathered-in when the Métis Settlements Act (MSA) was passed in $1990 .^{11}$

9 RCAP states:

It is indisputable that the distinct Métis Communities of Ontario-in locations as widespread as Burleigh Falls (near Peterborough), Moose Factory (on James Bay), Sault Ste. Marie and Rainy River (in the north and west of Thunder Bay) have long and unique histories, as well as indisputable claims to recognition of the Aboriginal rights and entitlements. The Métis community at Sault Ste. Marie, a hub of early fur-trade activity, has a particularly long and eventful history. It would appear, in fact, that the area was largely under Métis control from the late seventeenth to the mid-nineteenth century. The pre-eminence of a Métis family called Langlade has been noted by historians (4: 259-60).

10 The Federal Court of Canada, in its judgment in Daniels et al. v. Canada on 8 January 2013, states: THIS COURT'S JUDGMENT is that:

(a) the Court declares those persons who are Métis and those who are non-status Indians as set forth in the Reasons for Judgment are "Indians" within the meaning of the expression "Indians and Lands reserved for the Indians" contained in s 91(24) of the Constitution Act, 1867.

11 This principle is cited at paragraph (21) in the 2011 Supreme Court of Canada Judgment in Alberta v. Cunningham:

(21) ... the Transitional Membership Regulation, Alta. Reg. 337/90, permitted those registered on a settlement membership list upon the entry into force of the $M S A$ to maintain their membership even if they were already registered or were eligible to register as Indians under the Indian Act. 
Métis people who came forward in 1993 and 1994 did so because they were Métis, proud to be Métis and wanting to belong to a representative body that was both distinctly Métis and going to fight for Métis rights. "Grandfathering-in" their citizenship in the MNO a decade later was the right thing to do.

President Chartier writes:

The MNO policy also unilaterally defined the historic Métis Nation homeland based on a map adopted for purposes of harvesting rights which is appended to the policy. As long as a person can prove a connection to a geographic area covered by that map, they are entitled to be registered as a citizen of the Métis Nation. A portion of the map extends to the Ontario/Quebec border in the Mattawa/Ottawa region. ...

I want to point out that this map makes no reference to the Métis Nation Homeland. It was created because, in 2004, the MNO had successfully entered into an interim harvesting agreement with the Ontario Ministry of Natural Resources (MNR). The text on the map states:

This map shows, in a general way, the areas and terminology used in defining the Traditional Harvesting Territories of the Métis Nation in Ontario (MNO). The map is based on information accumulated in meetings and consultations with MNO citizens, by documents provided to the MNO Registry, and by research by MNO staff. This map was provided to the MNR during recent negotiations and will be used, for the time being, for the purposes of the MNO/MNR Interim Agreement on Harvesting. Traditional Harvesting Territories of the Métis Nation within Ontario can only be defined on an interim basis at this time. The map and description of the territories will be the subject of further research and consultations which will take place this fall.

President Chartier also writes, in reference to the map:

This clearly does not accord with the 1983 assertion of the geographic Métis Nation homeland territory made by the Métis Nation leadership....

In a document titled “The Métis: A Western Canadian Phenomenon" published in 1983, the MNC described the homeland as "encompassing the Prairie Provinces, north-eastern British Columbia, part of the Northwest Territories, northwestern Ontario and a portion of the northern United States.

A great deal has transpired since 1983, most significantly the constitutional recognition of the Métis right to hunt and fish for food by the Supreme Court of Canada in the case of $R$ v. Powley.

Steve and Roddy Powley, the two Métis men who were charged for illegal hunting of moose and who refused to plead guilty and pay a fine, which was normally what Métis people did, are from the historic Métis community of Sault Ste. Marie, Ontario. Steve and Roddy's ancestors attended the Robinson Treaty negotiations in 1850, but Robinson refused to negotiate with the men's ancestors because they were "half-breeds," saying he only had a mandate to negotiate with the "full bloods." Because of this fact, the courts ruled that their Métis right to hunt and fish for food was never extinguished, and therefore was an "existing" Aboriginal right that is protected and affirmed by s.35 of the Constitution Act, 1982. 
Sault Ste. Marie is far from northwestern Ontario. It's in the central part of the province. The Robinson Huron Treaty extends to the Ontario-Quebec border, and the Robinson Superior Treaty extends north to Treaty 9 territory. The "Williams Treaty" is in effect in the south near Peterborough, where the historic Métis community of Burleigh Falls is located.

The Court's criteria setting out who may exercise this right is not limited to a geographic territory in western Canada. Rather, it states:

In particular, we would look to three broad factors as indicia of Métis identity for the purpose of claiming Métis rights under s.35: self-identification, ancestral connection and community acceptance.

First, the claimant must self-identify as a member of a Métis community....

Second, the claimant must present evidence of an ancestral connection to a historic Métis community....

Third, the claimant must demonstrate that he or she is accepted by the modern community whose continuity with the historic community provides the legal foundation for the right being claimed....

Today, all Métis organizations that make up the Métis National Council rely on the Supreme Court of Canada ruling of $R v$. Powley in defence of Métis hunting and fishing rights, as in the current case of $R v$. Hersekorn, which is currently before the Alberta Court of Appeal, or to negotiate harvesting agreements. On 29 September 2012, the Manitoba Métis Federation announced it had reached such an agreement with the Government of Manitoba to provide for the recognition of Métis harvesting rights in parts of that Province. Its news release stated:

Based on rulings by the Supreme Court of Canada involving aboriginal rights for Métis people, the government of Manitoba is partnering with the Manitoba Métis Federation (MMF) to recognize Métis rights to harvest natural resources for food and domestic use in Manitoba, and to acknowledge the Métis peoples' commitment to conserve and respect the resources that sustain those rights, Premier Greg Selinger and David Chartrand, president of the Manitoba Métis Federation, announced today.

President Chartier writes:

The criteria used (in 1983) for identifying citizens of the Métis Nation had at its core those Métis who received land grants under the Manitoba Act 1870 and scrip under the various Dominion Lands Acts, and their descendants.

This self-definition was expressed again in the 1992 Métis Nation Accord, a companion document to the Charlottetown Accord, that was supported by the then Governing Members of the MNC along with the Métis from Ontario and the NWT. It provided that "Métis" means an Aboriginal person who self- identifies as Métis, who is distinct from Indian and Inuit and is a descendant of those Métis who received or were entitled to receive land grants and/or scrip under the provisions of the Manitoba Act, 1870 or the Dominion Lands Act, as enacted from time to time. 
President Chartier is a lawyer and, at the time, was one of the MNC's drafters. He would know that the above quotation is not all that was contained in the 1992 Métis Nation Accord concerning citizenship in the Métis Nation. It is but one of nine subsections under the Definitions heading in the Accord. The quote above is listed as paragraph 1.(a).

Paragraph 1. (b) is directly related and is as follows:

'Métis Nation' means the community of Métis persons in subsection a) and persons of Aboriginal descent who are accepted by that community. ${ }^{12}$

Section 17 of the Métis Nation Accord provided space for the signatories to the Accord. It is as follows:

17. Ratification Procedure

This Accord shall be considered adopted by the Métis Nation upon the passage of a duly authorized motion by a special assembly of elected Métis representatives of the Métis Nation as defined herein.

Below this section is the space and names of the signatories:

- Yvon Dumont, President, Métis National Council, Manitoba Métis Federation

- Norm Evans, President, Pacific Métis Federation

- Larry Desmeules, President, Métis Nation of Alberta

- Gerald Morin, President, Métis Society of Saskatchewan

- Gary Bohnet, President, Métis Nation-Northwest Territories

- Ron Swain, President, Ontario Métis Aboriginal Association

Space is also provided for the signature of representatives of the Governments of British Columbia, Alberta, Saskatchewan, Manitoba, Ontario, Canada, and the Northwest Territories.

It is very important that we fully reference and keep documents for future generations when we are talking about "issues" of Métis identity and citizenship within the Métis Nation. Because of the Native Council of Canada, the Métis National Council, its governing member organizations, and the work of all of the people involved, we are fortunate to have written material that we can rely on to guide us as we continue to consider the current debate and the development of our registries.

I believe we need to change the way that we think. I've had time to reflect since retiring from politics, and feel that as we continue the discussion that ultimately is intended to lead to the development of a Métis Nation Constitution, we should not only rely on the political and western ways of doing things, but also look to our traditional ways to guide us. It is also important not to forget the people involved in building our organizations, to leave them behind or discard them.

Very recently, I took part in an "internet town hall" about "Halfbreeds who withdrew from Treaty." The discussion inevitably drifted to the subject we seem to like to talk about the most-our identity.

12 A complete copy of the Proposed Métis Nation Accord is found in RCAP, 4: 376-81 
At one point, celebrated Métis author Maria Campbell from the Métis community of Park Valley in northern Saskatchewan said that, where she grew up, when Métis people were asked who they were, they would say they were "Indians" and then they would say they were Métis - "there was no difference between the two." She said Métis people referred to themselves as being Nêhiyawak (Crees) or Apihtawkosan (Apitaw means "half," kosan means "cousins"). ${ }^{13}$

During the same Internet Town Hall, our most famous Michif feature film actor, Tantoo Cardinal, said that as she was growing up in the Métis community of Anzac in the Fort McMurray area of Alberta, they always said they were "Indian." She said she knew she was different because she understood she didn't belong on the reserve. And in school, when children from the reserve were given new pencils and crayons, she wouldn't get them. Ironically, when she asked why, the teachers would say, it's because you're not Indian.

I'm reminded that in my historic Métis community of Lac Ste. Anne, Alberta, as I was growing up, the people said Nehiyaw Apihtawkosanak, meaning "we are Cree half-cousins." We lived on our own.

Although we share a similar history, culture, ancestors, territory, and traditions, one fact we need to realize is that the Métis are not a single homogeneous group. History shows that we have seen ourselves in different ways: either, in part, because of the European or First Nations ancestry that was fundamental in shaping our culture and customs, or in part because of the ways of life, depending on where we live. The basis of our Michif language changed depending on our ancestry, history, and territory. Michif in the Red River is distinct from the Michif spoken further west or further east.

I write to suggest that we now consider the geographic or territorial extent of the Métis Nation Homeland, not in terms of fixed positions taken at various points in our history, but on the basis of our evolving experience and knowledge. That too should be our guide as we continue to consider the current debate on Métis identity and the basis for citizenship within the Métis Nation.

Tony Belcourt

11 February, 2013

13 Nehiyawak and Apihtawkosan are Michif words for "Crees" and "half-cousins." In the Cree orthography, they are spelled Nêhiyawêwin and Apihtawikosisân. 